Pediat. Res. 7: 787-793 (1973)

Adenylate cyclase carbohydrate

epinephrine fetus, rhesus insulin muscle, skeletal

\title{
Effect of Insulin and Epinephrine on the Carbohydrate Metabolism and Adenylate Gyclase Activity of Rhesus Fetal Muscle
}

\author{
Rose Mary Bocek, ${ }^{[32]}$ Martha K. Young, and Glarissa H. Beatty \\ Division of Reproductive Biology, Oregon Regional Primate Research Center, Beaverton, Oregon, and Department of Biochemistry, \\ University of Oregon Medical School, Portland, Oregon, USA
}

\section{Extract}

Carbohydrate metabolism of skeletal muscle from rhesus fetuses at $58 \%$ of gestation (95 days) is sensitive to epinephrine in vitro. Epinephrine increased lactate production and decreased glucose uptake, ${ }^{14} \mathrm{C}$-lactate production, glycogen content, and ${ }^{14} \mathrm{C}$ glycogen formation as well as ${ }^{14} \mathrm{CO}_{2}$ production. These responses to epinephrine are similar to those in adult muscle. However, in some cases the magnitude of these responses appears lower in fetal muscle. The content of cyclic ${ }^{14} \mathrm{C}$-adenosine $3^{\prime}, 5^{\prime}$ monophosphate (cyclic ${ }^{14} \mathrm{C}$-AMP) was about 2.5-fold higher in the 100 -day fetal muscle than in the adult. Epinephrine stimulated adenylate cyclase activity almost threefold in fetal and fourfold in adult muscle. When incubated with muscle from 85-day fetal monkeys, insulin increased glucose uptake, lactate and lactate- ${ }^{14} \mathrm{C}$ production, and ${ }^{14} \mathrm{CO}_{2}$ production; the greatest effect was found in the increased incorporation of labeled glucose into glycogen. Both synthetase I and phosphorylase $a$ activities were present at 78-80 days of fetal age. Our data show that as early as about $58 \%$ of term the carbohydrate metabolism of fetal rhesus muscle in vitro is sensitive to epinephrine and that the hormone probably acts through the adenylate cyclase and the "second messenger" system of cyclic AMP as it does in adult muscle.

\section{Speculation}

Our data offer indirect evidence that insulin and epinephrine mediate glycogen metabolism via cyclic AMP in rhesus fetal muscle as early as 85 days of gestational age (52\% of term) and that these hormones operate through similar enzyme systems in fetal and adult muscle. It is possible that glycogen synthetase and phosphorylase, or other enzymes mediating the cyclic AMP response, are not identical in fetal and adult muscle; fetal isoenzyme patterns for muscle lactate dehydrogenase differ markedly from those of the adult. However, it is difficult to reconcile the existence of major differences in the enzyme milieu in fetal and adult muscle with the similar overall actions of epinephrine and insulin on glycogenesis and glycogenolysis demonstrated in our experiments. 


\section{Introduction}

Fetal endocrine glands have a physiologic function in the overall growth and development of the fetus [18, 23]. However, the role of specific hormones in regulating the metabolism of fetal target organs is still poorly understood.

In the primate and human fetus, placental transfer of insulin, if any, is small $[2,22]$, and the major source of fetal insulin is probably the fetal pancreas [1]. In early gestation (13-18 weeks), the human fetal pancreas is relatively unresponsive to increases in maternal [25] and fetal [2] blood sugar although there is insulin present in fetal blood and preparations of the isolated human fetal pancreas release insulin when challenged with physiologic stimuli other than glucose $[12,24]$. The fetal pancreas of the rhesus monkey is also unresponsive to a glucose challenge [22]. However, Freinkel [13] observed that the fetus is probably unresponsive to insulin for most of its intrauterine life. Clark et al. [10] were unable to show any effect of exogenous insulin on the incorporation of ${ }^{14} \mathrm{C}$ from glucose into lipid, glycogen, and protein in the 20-day fetal rat and concluded that although insulin was present in fetal rat serum, its role was unclear. These workers analyzed entire fetuses and pointed out that individual fetal tissues might yield different results. In a later paper Clark [8] suggested that the intact rat fetus had an endogenous insulin level that was sufficient to produce a maximal rate of glucose utilization. Other workers [19] were able to lower fetal rat blood glucose on day 20.5, 1 hr after insulin injection in utero, and Chez et al. [7] have reported evidence that insulin is biologically active in the rhesus fetus in vivo.

Epinephrine is present in the adrenal medulla of the human fetus at about 4 months of age $[1,15]$. To our knowledge, no data have been reported on the ontogeny of catecholamine production in the rhesus fetus, on the circulatory levels of epinephrine and norepinephrine, or on the placental transfer of these hormones, although Jost [17] believes that adrenomedullary hormones are probably not transferred from mother to fetus. Data on the effect of specific hormones such as insulin and epinephrine on the metabolism of individual fetal tissues in mammals is remarkably scarce.

In the present report, we have compared the effects of epinephrine in vitro on the carbohydrate metabolism of fetal and adult voluntary skeletal muscle from rhesus monkeys (Macaca mulatta) and have determined its effect on the adenylate cyclase system in the two series of animals. Previously [6] we demonstrated that, on a percentage basis, insulin was as effective in increasing the conversion of ${ }^{14} \mathrm{C}$-glucose to ${ }^{14} \mathrm{C}$-labeled glycogen, lactate, and $\mathrm{CO}_{2}$ in muscle from the rhesus fetus at 125 days $(76 \%)$ of gestational age as in muscle from the adult rhesus. We now find that rhesus fetal muscle as early as 85 days or $52 \%$ of gestational age is also sensitive to insulin. Data on glycogen synthetase and phosphorylase activities show that the active forms of both enzymes are present in fetal muscle as early as 80 days of fetal age.

\section{Methods}

Three series of five rhesus fetuses ( $M$. mulatta) were used in these experiments: 80-90 days of gestational age (designated 85 -day series or $52 \%$ of term) for the insulin study, 90-101 days (designated 95-day series or $58 \%$ of term) for the epinephrine experiments, and 100 days gestational age (61\% of term) for the adenylate cyclase activity determinations. The average gestation period in our colony is 165 days. The females had been placed with males for 3 days and the length of gestation was calculated from the 2nd day. The mothers were anesthesized intramuscularly with $1.0 \mathrm{mg} / \mathrm{kg}$ of 1 -(1phenylcyclohexyl)piperidine hydrochloride $[11,31]$ and the fetuses were removed and exsanguinated. Samples were taken from the muscles of the thigh; samples from the sartorius muscle of adult rhesus were obtained at biopsy. Muscle fiber groups were prepared and incubated as described [3].

\section{Metabolic Experiments}

For the insulin and epinephrine experiments, tissue samples were incubated in duplicate for $135 \mathrm{~min}$ in $2 \mathrm{ml}$ Krebs glycylglycine or bicarbonate-buffered medium, $\mathrm{pH} 7.4$, at $37^{\circ}$, containing $5.5 \mu$ moles glucose $/ \mathrm{ml}$ under either $100 \% \mathrm{O}_{2}$ or $95 \% \mathrm{O}_{2}+5 \% \mathrm{CO}_{2}$. U- ${ }^{14} \mathrm{C}$-Glucose ( 1 or $2 \mu \mathrm{Ci} / \mathrm{ml}$ ) was added at the end of a 15 -min equilibrium period. Media concentrations of hormones in the appropriate flasks were $10 \mathrm{mU} / \mathrm{ml}$ for insulin and $6 \times 10^{-6} \mathrm{M}$ for epinephrine. Lactate production into the medium, radioactivity in lactate, and $\mathrm{CO}_{2}$ were determined as described [3]. Tissues were digested in hot $30 \%$ $\mathrm{KOH}$ and the glycogen isolated with the technique of Good et al. [14]. Glycogen content and radioactivity in the glycogen fraction was determined as previously described [3]. Nitrogen was determined on muscle samples with the Technicon AutoAnalyzer after Kjeldahl digestion. Results are expressed in terms of the nitrogen content of muscle since metabolic activity is more closely associated with the nitrogen content of a given tissue than with dry or wet weight values. 


\section{Enzyme Assays}

Adenylate cyclase activity was determined from the formation of cyclic ${ }^{8-14} \mathrm{C}$-AMP from ATP labeled by incubation with $8-{ }^{14} \mathrm{C}$-adenine [21]. This technique does not quantitatively measure adenylate cyclase activity, inasmuch as all the labeled cyclic AMP produced may not be formed from the total pool of ATP. However, this method does give information on the sensitivity of the adenylate cyclase system to hormones in intact tissues [27]. Muscle fiber groups (80-150 $\mathrm{mg}$ ) from the hind limbs of rhesus fetuses at 100 days of gestational age or from the sartorius muscle of adult monkeys were incubated in Krebs HEPES-buffered medium (20 mM HEPES, $123 \mathrm{~mm} \mathrm{NaCl}, 2.5 \mathrm{~mm} \mathrm{KCl}, 1.8 \mathrm{~mm} \mathrm{CaCl}_{2}$, $0.62 \mathrm{~mm} \mathrm{KH}_{2} \mathrm{PO}_{4}$, and $0.62 \mathrm{~mm} \mathrm{MgSO}_{4}$ ) containing $100 \mathrm{mg} / 100 \mathrm{ml}$ glucose, $1 \%$ bovine serum albumin, and $1.7 \mu \mathrm{Ci} 8^{-14} \mathrm{C}$-adenine per ml, pH 7.4, at $37^{\circ}$ for $\mathrm{l} \mathrm{hr}$. At the end of this period, the ${ }^{14} \mathrm{C}$-labeled medium was removed, and the flask and tissues were rinsed with $1 \mathrm{ml}$ fresh, unlabeled adenine-free medium and reequilibrated for $5 \mathrm{~min}$ in a second 1-ml aliquot of unlabeled medium containing $1 \mathrm{mg} / \mathrm{ml}$ caffeine. Epinephrine equivalent to $6 \times 10^{-6} \mathrm{M}$ final concentration in the medium was then added to appropriate flasks from a sidearm. After an additional 10-min incubation, the tissues were quickly removed, drained, and immediately frozen in liquid nitrogen.

For cyclic AMP assay, the frozen tissues were placed in $0.5 \mathrm{ml}$ of a solution containing $12.5 \mathrm{~mm}$ carrier cyclic AMP, $40 \mathrm{~mm}$ ATP, and approximately $5 \times 10^{3} \mathrm{dpm}$ ${ }^{3} \mathrm{H}$-cyclic AMP and heated immediately for $10 \mathrm{~min}$ at $100^{\circ}$. The tissues were homogenized and centrifuged and the supernatant assayed for cyclic AMP according to the method of Krishna et al. [20] by passage through a column $(0.7 \times 5 \mathrm{~cm})$ of Dowex 50W-X8 (100-200 mesh) and elution with water. The fraction eluting between 2.5 and $6.5 \mathrm{ml}$ was collected and treated with $0.2 \mathrm{ml}$ each of $0.15 \mathrm{M} \mathrm{Ba}(\mathrm{OH})_{2}$ and $0.15 \mathrm{M} \mathrm{ZnSO}_{4}$; the precipitate was separated by centrifugation for $10 \mathrm{~min}$ at $3,000 \mathrm{rpm}$. A second addition of the $\mathrm{Ba}(\mathrm{OH})_{2}-\mathrm{ZnSO}_{4}$ was made to the cleared supernatant without disturbing the precipitate. Supernatant $(2 \mathrm{ml})$ was added to $15 \mathrm{ml}$ $20 \%$ Beckman Bio-Solv in 0.4\% Omnifluor in toluene, and the ${ }^{14} \mathrm{C}$ and ${ }^{3} \mathrm{H}$ activities were counted in a Philips liquid scintillation analyzer with dual label settings. Recovery of cyclic ${ }^{3} \mathrm{H}$-AMP averaged from $28-42 \%$.

Total glycogen synthetase and total phosphorylase activities and that of the active forms of the enzymes (synthetase I and phosphorylase a) were determined as described [5].

Data were analyzed on the basis of paired observa- tions and $P$ values calculated from the two-tailed $t$ test.

Results

The data in Table I indicate that the carbohydrate metabolism of skeletal muscle from rhesus fetuses at $58 \%$ of gestational age (95 days) is sensitive to epinephrine in vitro. Epinephrine increased unlabeled lactate production and decreased glucose uptake, ${ }^{14} \mathrm{C}$-lactate production, glycogen content, and ${ }^{14} \mathrm{C}$-glycogen formation as well as ${ }^{14} \mathrm{CO}_{2}$ production (Table $\mathrm{I}$ ). These metabolic responses to epinephrine in fetal muscle are similar to those in adult muscle (Table II); however, in some cases the magnitude of these responses appears lower in fetal muscle. For instance, on the basis of percentage of change with epinephrine, unlabeled lactate production increased $46 \%$ in fetal muscle and $188 \%$ in adult muscle. In quantitative terms, epinephrine increased lactate production by $0.30 \mu$ moles $/ \mathrm{mg} \mathrm{N} / 2 \mathrm{hr}$ in fetal and $0.49 \mu$ moles $/ \mathrm{mg} \mathrm{N} / 2 \mathrm{hr}$ in adult muscle. We have calculated from the specific activities of the lactate and substrate glucose (sp act lactate/sp act glucose $\times 100$ ) that in the control series, $69 \%$ of the lactate produced by fetal muscle and $75 \%$ by adult muscle originated from substrate glucose. With epinephrine these values decreased to $36 \%$ for fetal and

Table I. Effect of $6 \mu \mathrm{M}$ epinephrine on the metabolism of muscle fiber groups from the rhesus fetus (95 days of gestational age $)^{1}$

\begin{tabular}{|c|c|c|c|}
\hline & Control & $\begin{array}{l}\text { Change with } \\
\text { epinephrine }\end{array}$ & $\begin{array}{c}P \text { for } \\
\text { change }\end{array}$ \\
\hline $\begin{array}{l}\text { Glucose uptake, } \mu \text { moles/ } \\
\mathrm{mg} \mathrm{N} / \mathrm{hr}\end{array}$ & $0.46 \pm 0.02^{2}$ & $-0.059 \pm 0.009^{3}$ & $<0.01$ \\
\hline $\begin{array}{l}\text { Lactate production, } \\
\mu \text { moles } / \mathrm{mg} \mathrm{N} / \mathrm{hr}^{4}\end{array}$ & $0.65 \pm 0.06$ & $+0.301 \pm 0.006$ & $<0.005$ \\
\hline $\begin{array}{l}\text { Lactate production, } \\
\mathrm{dpm} \times 10^{4} / \mathrm{mg} \mathrm{N} / 2 \\
\mathrm{hr}\end{array}$ & $16.8 \pm 0.82$ & $-4.018 \pm 0.008$ & $<0.005$ \\
\hline $\begin{array}{c}\mathrm{CO}_{2} \text { production, dpm } \\
\times 10^{4} / \mathrm{mg} \mathrm{N} / 2 \mathrm{hr}\end{array}$ & $1.64 \pm 0.07$ & $-0.584 \pm 0.046$ & $<0.005$ \\
\hline Glycogen, $\mathrm{mg} / \mathrm{mg} \mathrm{N} \mathrm{N}^{5}$ & $0.76 \pm 0.03$ & $-0.090 \pm 0.018$ & $<0.01$ \\
\hline $\begin{array}{l}\text { Glycogen, dpm } \times 10^{4} / \\
\operatorname{mg~N}\end{array}$ & $2.28 \pm 0.02$ & $-1.278 \pm 0.137$ & $<0.005$ \\
\hline
\end{tabular}

${ }_{1}$ Analysis on duplicate flasks from five fetuses, except for the glycogen series, in which $n=3$. Statistical analysis on the basis of paired observations. Muscle fiber groups were incubated $135 \mathrm{~min}$ in $\mathrm{Krebs}$ bicarbonate-buffered medium, $\mathrm{pH} 7.4$, plus $5.5 \mu \mathrm{moles}$ glucose and $1 \mu \mathrm{Ci} U-{ }^{14} \mathrm{C}$-glucose $/ \mathrm{ml}$. Specific activity of glucose was $37.3 \times 10^{4} \mathrm{dpm} / \mu$ mole.

2 Mean $\pm \mathrm{se}$.

3 Difference $\pm \mathrm{sE}$.

4 Difference between concentrations in medium after 15 -min (equilibrium period) and 135 -min incubations.

5 Glucose equivalents; end of 2 -hr incubation. 
Table II. Effect of $6 \mu \mathrm{M}$ epinephrine on the metabolism of muscle fiber groups from adult rhesus monkeys ${ }^{1}$

\begin{tabular}{lccc}
\hline & Control & $\begin{array}{c}\text { Change with } \\
\text { epinephrine }\end{array}$ & $\begin{array}{c}P \text { for } \\
\text { change }\end{array}$ \\
\hline $\begin{array}{l}\text { Glucose uptake, } \mu \text { moles/ } \\
\text { mg N/hr }\end{array}$ & $0.26 \pm 0.01^{2}$ & $-0.34 \pm 0.004^{3}$ & $<0.005$ \\
$\begin{array}{l}\text { Lactate production, } \\
\mu \text { moles } / \mathrm{mg} \mathrm{N} / \mathrm{hr}\end{array}$ & $0.26 \pm 0.02$ & $+0.462 \pm 0.025$ & $<0.005$ \\
$\begin{array}{l}\text { Lactate production, } \\
\mathrm{dpm} \times 10^{4} / \mathrm{mg} \mathrm{N} / 2\end{array}$ & $16.8 \pm 1.3$ & $+0.420 \pm 0.500$ & $\mathrm{NS}$ \\
$\mathrm{hr}$ & & & \\
$\begin{array}{l}\mathrm{CO}_{2} \text { production, dpm } \\
\times 10^{4} / \mathrm{mg} \mathrm{N} / 2 \mathrm{hr}\end{array}$ & $2.44 \pm 0.17$ & $-0.880 \pm 0.084$ & $<0.01$ \\
$\begin{array}{l}\text { Glycogen, mg/mg N4 } \\
\text { Glycogen, dpm } \times 10^{4} /\end{array}$ & $0.29 \pm 0.02$ & $-0.118 \pm 0.029$ & $<0.005$ \\
mg N & $4.62 \pm 0.42$ & $-3.521 \pm 0.588$ & $<0.005$ \\
\hline
\end{tabular}

${ }^{1}$ Statistical analysis on the basis of paired observations, five monkeys (duplicate flasks). The conditions of experiment were the same as given in Table I except that the specific activity of the glucose was $85 \times 10^{4} \mathrm{dpm} / \mu \mathrm{mole}$. NS: not signifant.

$2 \mathrm{Mean} \pm \mathrm{SE}$

3 Difference $\pm \mathrm{sE}$

4 Glucose equivalents; end of 2-hr incubation.

$25 \%$ for adult muscle. Assuming a minimal amount of lactate produced from noncarbohydrate sources, $31 \%$ of the lactate in the fetal series and $25 \%$ in the adult series arose from glycogen breakdown. After epinephrine, these values were increased to $64 \%$ and $75 \%$, respectively. In preliminary experiments, no differences were found in metabolic responses at $3 \times 10^{-6} \mathrm{M}$ and $6 \times 10^{-6} \mathrm{M}$ concentrations of epinephrine. Therefore, the latter was considered to be a maximal concentration.

The decrease in ${ }^{14} \mathrm{C}$-lactate production induced by epinephrine in the fetal series but not in the adult cannot be explained on the basis of the lowered glucose uptake alone, inasmuch as the decrease in ${ }^{14} \mathrm{C}$-glucose uptake with epinephrine was similar in both series $(13 \%$ and $11 \%)$. However, the decreased incorporation of ${ }^{14} \mathrm{C}$ label into glycogen was greater in adult muscle (3.5 $\mathrm{dpm} \times 10^{4} / \mathrm{mg} \mathrm{N}$, Table II $)$ than in fetal muscle $(1.3 \times$ $10^{4} \mathrm{dpm} / \mathrm{mg} \mathrm{N}$, Table I); therefore, in the adult series with epinephrine, the additional ${ }^{14} \mathrm{C}$-glucose made available for utilization via the glycolytic cycle masked the effect of a decrease in ${ }^{14} \mathrm{C}$-glucose uptake. The glucose-to-glycogen pathway appears to be at least as active in fetal as in adult muscle. When the actual amounts of glucose converted to glycogen during the experimental period were estimated, fetal muscle converted $61 \mu$ moles $/ \mathrm{g} \mathrm{N} / 2 \mathrm{hr}$ of glucose to glycogen and adult muscle converted $54 \mu$ moles/g N/2 hr.

In the presence of caffeine $(1 \mathrm{mg} / \mathrm{ml})$, the content of ${ }^{14} \mathrm{C}$-cyclic AMP was about 2.5-fold higher in the 100-day fetal muscle than in the adult (Table III). Epinephrine stimulated adenylate cyclase activity almost threefold in fetal and fourfold in adult muscle; however, the absolute increase in fetal muscle was twice that in the adult.

When incubated with muscle fiber groups from 85-day fetal monkeys, insulin increased glucose uptake, lactate and ${ }^{14} \mathrm{C}$-lactate production, and ${ }^{14} \mathrm{CO}_{2}$ production (Table IV); the greatest effect was found in the in-

Table III. Effect of $6 \mu \mathrm{M}$ epinephrine on the cyclic ${ }^{14} \mathrm{C}$-adenosine monophosphate (cyclic ${ }^{14} \mathrm{C}$-AMP) content of 100-day fetal and adult rhesus skeletal muscle ${ }^{1}$

\begin{tabular}{lcccc}
\hline \hline & & \multicolumn{3}{c}{ Cyclic ${ }^{14}$ C-AMP } \\
\cline { 3 - 5 } & $n$ & Control & $\begin{array}{c}\text { Increase with } \\
\text { epinephrine }\end{array}$ & $\begin{array}{c}P \text { for } \\
\text { iecrease }\end{array}$ \\
\hline Fetal & 5 & $764 \pm 76$ & $+2223 \pm 142$ & $<0.001$ \\
$\begin{array}{l}\text { Adult } \\
P \text { fetal }\end{array}$ & 7 & $285 \pm 65$ & $+1046 \pm 163$ & $<0.001$ \\
$\quad$ adult & & $<0.001$ & $<0.001$ & \\
\hline
\end{tabular}

${ }^{1}$ Values are means \pm sE. Statistical analysis on the basis o paired observations. $n$ is the number of experiments run in duplicate. Tissues were incubated for $1 \mathrm{hr}$ in HEPES-buffered Krebs medium, $\mathrm{pH} 7.4$, at $37^{\circ}$ containing $1 \%$ albumin, $100 \mathrm{mg} /$ $100 \mathrm{ml}$ glucose and $1.7 \mu \mathrm{Ci} 8-^{14} \mathrm{C}$-adenine $/ \mathrm{ml}$ and then in nonlabeled medium containing $1 \mathrm{mg}$ caffeine $/ \mathrm{ml}$ with and without $6 \mu \mathrm{M}$ epinephrine for $10 \mathrm{~min}$. Tissues were frozen and stored in liquid $\mathrm{N}_{2}$. Cyclic AMP was determined on the supernatant after homogenization according to the method of Krishna et al. [20]. For additional details, see Methods.

Table IV. Effect of insulin $(10 \mathrm{mU} / \mathrm{ml})$ on the metabolism of muscle fiber groups from 85 -day fetal rhesus monkeys ${ }^{1}$

\begin{tabular}{|c|c|c|c|}
\hline & Control & + Insulin & $P$ \\
\hline $\mathrm{QO}_{2}, \mu$ moles $/ \mathrm{mg} \mathrm{N} / \mathrm{hr}$ & $2.51 \pm 0.09$ & $2.45 \pm 0.001$ & NS \\
\hline $\begin{array}{l}\text { Glucose uptake, } \mu \text { moles } / \mathrm{mg} \\
\mathrm{N} / \mathrm{hr}\end{array}$ & $0.54 \pm 0.04$ & $0.57 \pm 0.03$ & $<0.05$ \\
\hline $\begin{array}{l}\text { Lactate production, } \mu \text { moles/ } \\
\mathrm{mg} \mathrm{N} / \mathrm{hr}^{2}\end{array}$ & $0.60 \pm 0.03$ & $0.74 \pm 0.01$ & $<0.02$ \\
\hline $\begin{array}{l}\text { Lactate production, } \mathrm{dpm} \times \\
10^{4} / \mathrm{mg} \mathrm{N} / 2 \mathrm{hr}\end{array}$ & $18.3 \pm 3.0$ & $23.8 \pm 0.8$ & $<0.001$ \\
\hline $\begin{array}{l}\mathrm{CO}_{2} \text { production, dpm } \\
10^{4} / \mathrm{mg} \mathrm{N} / 2 \mathrm{hr}\end{array}$ & $1.82 \pm 0.12$ & $2.12 \pm 0.15$ & $<0.001$ \\
\hline Glycogen, $\mathrm{mg} / \mathrm{mg} \mathrm{N}$ & $0.63 \pm 0.04$ & $0.62 \pm 0.04$ & NS \\
\hline Glycogen, $\mathrm{dpm} \times 10^{4} / \mathrm{mg} \mathrm{N}$ & $1.69 \pm 0.17$ & $2.48 \pm 0.23$ & $<0.001$ \\
\hline
\end{tabular}

1 Values are means $\pm \mathrm{SE}$ for five fetuses. Statistical analysis on the basis of paired observations. Muscle fiber groups were incubated for $135 \mathrm{~min}$ in Krebs glycylglycine-buffered medium, $\mathrm{pH} 7.4$, at $37^{\circ}$ plus $5.5 \mu$ moles U.I4C-glucose/ml. Specific activity of glucose in the medium was $37.3 \times 10^{4} \mathrm{dpm} / \mu$ mole glucose. U. ${ }^{14} \mathrm{C}$-Glucose $(1 \mu \mathrm{Ci} / \mathrm{ml}$ medium) was added at the end of the 15 -min equilibrium period. NS : not significant.

${ }^{2}$ Difference between concentrations in medium after $15-\min$ (equilibrium period) and 135 -min incubations. 
Table V. Glycogen synthetase and phosphorylase activities in muscle from 78-80-day fetal rhesus monkeys ${ }^{1}$

\begin{tabular}{lc}
\hline & Activity \\
\hline Glycogen synthetase & \\
Total activity & $14.4 \pm 1.0$ \\
Synthetase I & $1.5 \pm 0.6$ \\
Synthetase I, $\%$ & 10.5 \\
& \\
Phosphorylase & \\
Total activity & $8.6 \pm 0.4$ \\
Phosphorylase $a$ & $2.6 \pm 0.7$ \\
Phosphylase $a, \%$ & 28.5 \\
\hline
\end{tabular}

1 Values are means $\pm \mathrm{SE}$ of duplicate analyses on each of two muscle samples from eight fetuses.

${ }^{2}$ Micromoles of UDP per minute per $100 \mathrm{mg} \mathrm{N}$.

${ }^{3}$ Micromoles of $\mathrm{P}$ per minute per $100 \mathrm{mg} \mathrm{N}$.

creased incorporation of labeled glucose into glycogen. Oxygen consumption and the glycogen content of muscle were unaffected by insulin.

In a limited series of three 78-day rhesus fetuses, we reported [4] that no significant synthetase I or phosphorylase $a$ activity could be demonstrated in muscle since the average values were not significantly different from 0 . When five or more fetuses at 80 days of gestational age were added to the series subsequently, both synthetase $I$ and phosphorylase $a$ activities were present at 78-80 days of fetal age (Table V).

\section{Discussion}

Hormones participate in the overall metabolic regulation and the maintenance of homeostasis during prenatal and postnatal life. The ability to regulate metabolism depends on adjusting secretory activity to respond to need. The fetus, for example, may secrete glucose independently to maintain its blood glucose levels during periods of maternal hypoglycemia [19]. Thus, although the mother is the source of energy in utero, the fetus does maintain some independent control of its metabolism. A second factor in hormonal regulation of metabolic control depends on the sensitivity of target organs to hormones. Our data show that as early as about $58 \%$ of term the carbohydrate metabolism of fetal rhesus muscle in vitro is sensitive to epinephrine and that the hormone probably acts through the adenylate cyclase and the "second messenger" system of cyclic AMP as it does in adult muscle. The effects of epinephrine on the metabolic parameters measured in these experiments (decreased incorporation of ${ }^{14} \mathrm{C}$ into glycogen and increased lactate production) can be explained by the action of the hormone on adenyl cyclase to increase intracellular levels of cyclic AMP. In adult muscle, this nucleotide increases the activity of a protein kinase [26], which activates phosphorylase $b$ kinase to convert inactive phosphorylase $b$ to active phosphorylase $a$ and cause glycogen breakdown. Protein kinase also phosphorylates glycogen synthetase, converting it from an active (I) to an inactive (D) form and thereby depressing glycogen synthesis [26]. Increased tissue levels of glucose-6- $\mathrm{PO}_{4}$ have been shown to inhibit hexokinase in adult muscle [29]. In our experiments, epinephrine decreased glucose uptake in both fetal and adult muscle. This decrease in glucose uptake could be explained by an increased level of tissue glucose-6- $\mathrm{PO}_{4}$ caused by the increased glycogenolysis with epinephrine. This is evidence that the hexokinase of fetal muscle is sensitive to changes in levels of glucose-6-PO ${ }_{4}$. Epinephrine increased lactate production in both series mainly from unlabeled glycosyl units of glycogen, yielding a lactate pool of lower specific activity which was reflected in the lowered production of ${ }^{14} \mathrm{CO}_{2}$. A decreased incorporation of label into glycogen would result from the cyclic AMPmediated decrease in the active form of glycogen synthetase, and from a lowered glucose uptake as well as increased breakdown of newly formed labeled glycogen.

The mechanism by which insulin promotes glycogen synthesis is controversial. An insulin-mediated increase in cyclic AMP phosphodiesterase activity has been reported [28]. Others have suggested that insulin promotes formation of an inactive complex of protein kinase [30]. Lowered intracellular levels of cyclic AMP or direct protein kinase inactivation would allow the balance of synthetase I to D interconversions to shift toward the I or active form and glycogen synthesis. Since synthetase I and phosphorylase $a$ activities are present in significant amounts in fetal muscle at 80 days of gestational age, the potential for hormonal control of glycogen metabolism by epinephrine via cyclic AMP and by insulin is probably similar in fetal and adult muscle.

From the data of Hommes and Beere [16], we estimate that the adenyl cyclase activity as measured by the conversion of ${ }^{14} \mathrm{C}$-ATP to cyclic ${ }^{14} \mathrm{C}$-AMP in skeletal muscle of the fetal rat was about 15-fold lower than that of adult muscle. In our experiments, the activity of the enzyme was twofold higher in fetal than in adult rhesus muscle in both the control and epinephrine series. Variation in the species used may explain the differences, inasmuch as, in terms of percentage of gestational age, striking differences in the occurrence of endocrine events have been demonstrated between man and the rat [18] 
Differences between adenylate cyclase activities in fetal and adult muscle of the rat and rhesus monkey may be due to other factors which are not directly associated with the enzyme action itself but which operate indirectly to affect the enzyme assay system. Variation in pool sizes and rates of turnover of precursor nucleotides would influence the amount of radioactivity found in the cyclic AMP isolated. Moreover, the tissues assayed contain phosphodiesterase, the enzyme that converts cyclic AMP to 5'-AMP. If the phosphodiesterases in fetal and adult muscle varied in activity or sensitivity to the inhibitory effects of caffeine, a greater or lesser rate of cyclic AMP degradation in the assay mixture would result.

The values found for $\mathrm{Q}_{2}$ and glucose uptake in the 85-day rhesus fetal muscle were higher than those for a 125 -day series $\left(\mathrm{Q}_{\mathrm{O}_{2}}, 1.2 \pm 0.1 \mathrm{SE} \mu\right.$ moles $/ \mathrm{mg} \mathrm{N} / \mathrm{hr}$, glucose uptake, $0.30 \pm 0.04 \mu \mathrm{mole} / \mathrm{mg} \mathrm{N} / \mathrm{hr}$ ) [6]. The response of 85-day fetal muscle to insulin generally paralleled that of fetal muscle at 125 days [6], although, in terms of the percentage change with insulin the effect on glucose uptake, ${ }^{14} \mathrm{CO}_{2}$ production and conversion of glucose to glycogen was lower in the younger fetus. Clark [9] reported that insulin increases ${ }^{1-14} \mathrm{C}$-glucose uptake by fetal rat heart but had no effect on lactate or ${ }^{14} \mathrm{CO}_{2}$ production. However, insulin increased the incorporation of labeled glucose into the cold trichloroacetic acid (TCA)-extractable fraction of glycogen but not the hot $\mathrm{KOH}$-extractable fraction. It was concluded that, in fetal rat heart, a major portion of ${ }^{14} \mathrm{C}$-glucose was incorporated into the outermost tiers of the glycogen molecule and that this incorporation was increased by insulin. In rhesus fetal muscle insulin increased the incorporation of ${ }^{14} \mathrm{C}$-glucose into the $\mathrm{KOH}$-extractable glycogen; the effect on the TCA-extractable glycogen was not measured.

\section{Summary}

Voluntary skeletal muscle from rhesus fetuses as early as 95 days of gestational age (about $58 \%$ of term) was responsive to epinephrine in vitro. Epinephrine stimulated the adenylate cyclase system in fetal as well as in adult muscle; however, the level of activity in fetal muscle was about twofold higher than in adult muscle. Epinephrine decreased glucose uptake and incorporation into glycogen and stimulated glycolysis and glycogenolysis in fetal muscle. Insulin increased glucose uptake and glycogenesis in fetal muscle at 85 days of gestational age $(52 \%$ of term). Both inactive and active forms of glycogen synthetase and phosphorylase were present in rhesus fetal muscle at 80 days of fetal age, and presumably, the interconversion of the two forms of the enzymes is responsive to epinephrine and insulin. If these results in vitro reflect metabolic conditions in vivo, then, irrespective of the source of the hormones, maternal or fetal, both insulin and epinephrine affect metabolic pathways in fetal muscle in a way that is qualitatively similar to that in adult muscle.

\section{References and Notes}

1. Adam, P. A. J.: Control of glucose metabolism in the human fetus and newborn infant. In: Advances in Metabolic Disorders, Vol. 5, p. 183 (Academic Press, New York-London, 1971).

2. Adam, P. A. J., Teramo, K., Rärhä, N., Gitlin, D., and Schwartz, R.: Human fetal insulin metabolism early in gestation: response to acute elevation of the fetal glucose concentration and placental transfer of human insulin-I-131. Diabetes, 18: 409 (1969).

3. Beatty, C. H., Basinger, G. M., and Bocek, R. M.: Pentose cycle activity in muscle from fetal, neonatal, and infant rhesus monkeys. Arch. Biochem. Biophys., 117: 275 (1966).

4. Bocer, R. M., Basinger, G. M., ANd Beatty, C. H.: Glycogen synthetase, phosphorylase, and glycogen content of developing rhesus muscle. Pediat. Res., 3: 525 (1969).

5. Bocek, R. M., AND BeAtTy, C. H.: Glycogen synthetase and phosphorylase in red and white muscle of the rat and rhesus monkey. J. Histochem. Cytochem., 14: 549 (1966).

6. Bocek, R. M., and Beatty, C. H.: Effect of insulin on the carbohydrate metabolism of fetal rhesus monkey muscle. Endocrinology, 85: 615 (1969).

7. Chez, R. A., Mintz, D. H., Horger, E. O., III, and HutCHIsON, D. L.: Factors affecting the response to insulin in the normal subhuman pregnant primate. J. Clin. Invest., 49: 1517 (1970).

8. Clark, C. M., JR.: Carbohydrate metabolism in the isolated fetal rat heart. Amer. J. Physiol., 220: 583 (1971).

9. Cllark, C. M., JR.: Characterization of glucose metabolism in the isolated rat heart during fetal and early neonatal development. Diabetes, 22: 41 (1973).

10. Clark, C. M., Jr., Cahill, G. F., Jr., and Soeldner, J. S.: Effects of exogenous insulin on the rate of fatty acid synthesis and glucose ${ }^{-14} \mathrm{C}$ utilization in the twenty-day rat fetus. Diabetes, 17: 362 (1968).

11. Domino, E. F., MaGarthy, D. A., and Deneau, G. A.: General anesthesia in infrahuman primates. Fed. Proc., 28: 1500 (1969).

12. Espinosa de los Monteros, M. A., Driscoll, S. G., And STEINKE, J.: Insulin release from isolated human fetal pancreatic islets. Science, 168: 111 (1970).

13. Freinkel, N.: Homoeostatic factors in fetal carbohydrate metabolism. In: Fetal Homeostasis, p. 85 (Appleton-CenturyCrofts, New York, 1969).

14. Good, C. A., Kramer, H., and Somogyi, M.: The determination of glycogen. J. Biol. Chem., 100: 485 (1933).

15. Greenberg, R. E., and Lind, J.: Catecholamine in tissues of the human fetus. Pediatrics, 27: 904 (1961).

16. Hommes, F. A., ANd Beere, A.: The development of adenyl 
cyclase in rat liver, kidney, brain, and skeletal muscle. Biochim. Biophys. Acta, 237: 296 (1971).

17. Jost, A.: Problems of fetal endocrinology: The adrenal glands. In: Recent Progress in Hormone Research, Vol. 22, p. 541 (Academic Press, New York-London, 1966).

18. Jost, A.: The extent of foetal endocrine autonomy. In: Foetal Autonomy, p. 79 (Ciba Foundation Symposium, Churchill, London, 1969).

19. Josr, A., And Picon, L.: Hormonal control of fetal development and metabolism. In: Advances in Metabolic Disorders, Vol. 4, p. 123 (Academic Press, New York-London, 1970).

20. Krishna, G., Weiss, B., and Brodie, B. B. : A simple, sensitive method for the assay of adenyl cyclase. J. Pharmacol. Exp. Ther., 163: 379 (1968).

21. Laraia, P. J., and Reddy, W. J.: Hormonal regulation of myocardial adenosine $3^{\prime}, 5^{\prime}$-monophosphate. Biochim. Biophys. Acta, 177: 189 (1969).

22. Little, W. A., Nasser, D., and Spellaagy, W. N.: Carbohydrate metabolism in the primate fetus. Amer. J. Obstet. Gynecol., 109: 732 (1971).

23. MacNaughton, M. C.: Endocrinology of the fetus. In: Foetus and Placenta, p. 557 (Blackwell Scientific Publications, Oxford and Edinburgh, 1969).

24. Milner, R. D. G., Ashworth, M. A., and Barson, A. J.: Insulin release from human foetal pancreas in response to glucose, leucine, and arginine. J. Endocrinol., 52: 497 (1972).

25. Obenshain, S. S., Adam, P. A. J., King, K. C., Teramo, K., Ravio, K. O., Rärn̈̈, N., AND Schwartz, R.: Human fetal insulin response to sustained maternal hyperglycemia. New Engl. J. Med., 283: 566 (1970).
26. Robison, G. A., Butcher, R. W., and Sutherland. E. W.: Cyclic AMP, p. 142 (Academic Press, New York-London, 1971).

27. Rodbell, M.: In vitro assays of adenyl cyclase. Acta Endocrinol. Suppl., 153: 337 (1971).

28. Senft, G., Schultz, G., Munske, K., and Hoffman, M.: Influence of insulin on cyclic $3^{\prime}, 5^{\prime}$-AMP phosphodiesterase activity in liver, skeletal muscle, adipose tissue and kidney. Diabetologia, 4: 322 (1968).

29. Sols, A.: Hexokinase and glucokinase. In: Control of Glycogen Metabolism, p. 301 (Ciba Foundation Symposium, Little, Brown and Co., Boston, 1964).

30. Walaas, O., AND WalaAs, E.: Inhibition of protein kinase in the isolated rat diaphragm (Abstract). In: Advances in Cyclic Nucleotide Research, Vol. 1, p. 590 (Raven Press, New York, 1972).

31. Sernylan, Bioceutic Laboratories, Inc., St. Joseph, Mo.

32. Publication No. 661 of the Oregon Regional Primate Research Center, supported by part by Grant RR-00163 of the National Institutes of Health. This investigation was supsported in part by Public Health Service Research Grants HD-06069 and HD-06425, and General Research Support Grant Public Health Service RR-05694, National Institutes of Child Health and Human Development, and by the Muscular Dystrophy Association of America, Inc.

33. Requests for reprints should be addressed to: R. M. BoceK, Ph.D., Oregon Regional Primate Research Center, 505 N. W 185th Ave., Beaverton, Oregon 97005 (USA).

34. Accepted for publication May 16, 1973. 